\title{
Operating Efficiency and Firm Valuation: Evidence from India
}

\author{
DyalBhatnagar \\ Punjabi University, India \\ dyalbhatnagar@gmail.com \\ Chandra ShekharBhatnagar \\ The University of the West Indies, Trinirdad \\ Chandrashekhar.bhatnagar@sta.uwi.edu \\ Pritpal Singh Bhullar \\ Assistant Professor, GZSPTU Campus, Bathinda \\ bhullar_pritpal36@yahoo.co.in
}

\begin{abstract}
We examine the impact of operating efficiency on firm valuation. The study spans ninety firms spread over six major industrial sectors in India from 2005 through 2012. Six key ratios are considered for their possible impact on the enterprise value. Through panel data analysis, we find that gross profits, return on capital employed asset turnover and to some degree, sales have a significant impact on the enterprise value at the inter-industry level. In the collective sample, all six ratios pertaining to operating efficiency and profitability have a significant effect on enterprise value. We also note that with the infrastructure sector as the reference point, the role of banking sector is significantly positive in value creation. Further, value creation is more attendant to present performance rather than what might have happened in the past.
\end{abstract}

Keywords: Operating efficiency, Panel Data Analysis, EV/EBITDA, Enterprise Value, Firm Value

\section{Introduction}

Firms continuously try to scout and opt for opportunities of achieving competitive advantage in an increasingly complex and competitive environment through organic and inorganic growth. Since it is sometimes considered a faster way to grow, corporate restructuring (inorganic growth) has emerged as a popular strategy among big and medium size corporate houses. The importance of a firm's valuation in this context cannot be overstated, for it establishes the price of a target firm, which, if not determined correctly, would lead to a loss to the acquiring or the target firm.

Our goal in this paper is to see how a firm's operating efficiency affects its value. Seetharaman and Raj (2011) report a strong positive correlation between EPS and the stock price of Public Bank Barhad, a listed bank in Malaysia. We, however, avoid conventional measures like Earnings-per-Share $(E P S)$ and Price-to-earnings $(P / E)$ because when the total income of a firm is derived primarily from non-operating sources, the reality about a firm's operational efficiency may be obscured, if not hidden altogether. Naik (2007) had also considered variables like operating profit and expenses in his study on the operating efficiency of banks.

Jin and Jin (2008) report a positive correlation between operating performance and stock price change among the top 10\% performers on the Shanghai Stock Exchange in the first two years of research period but in the latter period of two years, operating performance is inversely proportional to stock price change. Their principal finding is that operating performance generally declined as the stock prices went up. Similarly, Kirkwood and Nahm (2006) report that changes in firm efficiency are reflected in stock returns. Beccalli, Casu and Girardone, (2006) also find that changes in efficiency are reflected in changes in stock prices and that the stocks of cost efficient banks tend to outperform their inefficient counterparts. Earlier, Chu and Lim (1998) had also found that percentage changes in the prices of the bank shares reflect percentage changes in profit.

In this paper, we propose the use of Enterprise Value $(E V)$ as a proxy for firm's value. We believe that rather than valuing only the underlying stock of a firm, the valuation measure should be more broad based. $E V$ values a firm based on its entire capital structure that includes a firm's debt, cash and minority interests. As $E V$ takes debt into account; it relates the total value of a firm to a measure of operating earnings generated (such as earnings before interest, taxes, depreciation, and amortization). This should represent a more accurate picture of a firm's value in terms of its theoretical takeover price. Also the Stock Price is much more volatile than Enterprise value. Two firms may have same or nearly same stock price even though they have been leveraged differently. Buying the stock of firm with debt means investor is also taking over the liabilities of company along with assets. 
As noted earlier, most studies, which examine value creation and operational efficiency in the banking sector [Ioannidiset al (2007), Becalliet al (2006), Chu and Lim (1998)]. We expand the scope of our work beyond the banking sector by introducing Information Technology (IT), Pharmaceuticals, Fast Moving Consumer Goods (FMCG), Automobile and Infrastructure sectors in our analysis.

The remainder of the paper is organized as follows: Section II reports the data and methods. Section III presents the main findings. Section IV concludes the paper.

\section{Data and Methods}

We employ panel data analysis to analyze the impact of operating efficiency on the valuation of firms. Six industrial sectors from the Indian economy are considered for analysis. Data for 90 firms (15 firms from each sector with largest market capitalization, where possible ${ }^{1}$ ) from the year 2005 through 2012 have been collected from the Capitaline Database and annual reports of sample firms. A list of firms comprising the sample is placed at Appendix 1.

Enterprise Value $(E V)$ as a measure of firm value is the dependent variable.

The independent variables include:

i) $\frac{E V}{E B I T D A}$, where $E V$ is the Enterprise value and EBITDA is the Earnings before Interest, Tax, Depreciation and Amortization

The rationale behind using $\frac{E V}{E B I T D A}$ over P/E is that EBITDA is before tax earnings whereas EPS is post tax earnings. Additionally, $\frac{E V}{E B I T D A}$ considers debt and cash position on the balance sheet of company whereas $P / E$ does not consider cash position on the balance sheet of company. Going forward, we refer to this ratio is $R_{l}$

ii) Return on Capital Employed (ROCE). We will call this ratio $R_{2}$

iii) $\frac{E V}{S}$, where $S$ is the Sales. This ratio is named $R_{3}$

iv) $\frac{C F O A}{S}$, where $C F O A$ is the cash flow from operating activities. This relationship is named $R_{4}$ and likewise the next two are $R_{5}$ and $R_{6}$

v) Fixed Asset Turnover Ratio (FATO), and

vi) Net Profit Margin (NPM)

A brief description of these variables is given in Appendix 2

The following general OLS model can be used to study the effect of identified independent variables (ratios) on the dependent variable $(E V)$ :

$$
E V_{i}=\alpha+\sum_{j=1}^{J} \beta_{j} R_{j, i}+\varepsilon_{i}
$$

Where $E V_{i}$ is the Enterprise value of the $i^{\text {th }}$ entity and $j$ are the various ratios.

As mentioned earlier, we decided to use panel data. The motivation was to avoid endogeneity among independent variables. Endogeneity can arise if one; the direction of causality is from the dependent variable to independent variables, in which case, the model would be mis-specified or two; the causality is bi-directional. The third possibility for endogeneity would be the presence of another variable affecting both the independent and dependent variables and the resulting effect would be present in the error term of equation (1), leading to inconsistent and biased coefficient estimates.

\footnotetext{
${ }^{1}$ Strictly adhering to large-cap firms was not possible due to missing data for some firms and differences in their financial years.
} 
By construction, the identified independent variables appear exogenous. The possibility of either $E V$ affecting various ratios or a bi-directional causality between $\mathrm{EV}$ and various ratios is not likely.

However, there could be unobservable or non-quantifiable factors like the difference in corporate culture, the quality of management and business practices at the industry or firm level. Further, $E V$ could change with time. We hypothesize the Enterprise Value $(E V)$ should be more closely related with either the current operational efficiency or at best by the carry-forward effect of being efficient in the past. However, the farther we go back in time, the relationship between $E V$ and past efficiency should be penalized in that the current value of the firm should not be a result of being efficient (or inefficient) in the distant past. To account for such unobservables and to avoid the omitted variable bias, we decided to use dummy variables for firms/industries and time. To carry out the analysis, the fixed effects model was chosen. We understand that in using the fixed effects model, we are implicitly assuming that though the firms/industries have their unique attributes, this heterogeneity is constant over time. While this may not be true, we considered mitigating variable endogeneity to be more crucial and therefore, our choice of the fixed effects model. To put our minds at rest, we used the Hausman test to see whether a random effects model would be preferable and as reported in the next section, the result was negative. As such, we initiated the analysis as per the model specified in equation 2 though the dummy variables for industries had to be dropped during inter-industry analysis due to collinearity.

$$
E V_{i t}=\alpha+\beta_{1} R_{1 t}+\ldots \ldots . .+\beta_{j} R_{j t}+\chi_{2} D_{2 t}+\ldots \ldots .+\chi_{k} D_{k t}+\delta_{2} T_{2}+\ldots \ldots+\delta_{t} T_{t}+\mu_{i t}
$$

where $E V_{i t}$ is the enterprise value of the $i^{\text {th }}$ entity in time $t . D$ are the dummy variables for industries and $T$ are the dummy variables for time.

\section{Results and Discussion}

We ran regressions on the panel data using both the fixed and random effects. While using fixed effect model, apart from the list of independent variables, we used dummy variables for time as well as firms.

The analysis was two-fold: One, at an aggregate level, which included all industries (all 90 firms together) and two, at the inter industry level, where firms from each industry were studied separately from others.

In case of the aggregate sample (all industries collectively), we used dummy variables for time and industries.

When working with individual industries, we debated on whether to include dummy variables for firms that comprise the industry group in question. Since each group had fifteen firms, it would mean giving up valuable degrees of freedom. Further, we expected that due to a broad pervasive similarity amongst firms within an industry, there would be excessive collinearity and our initial analysis did, in fact, confirm this. When included, they had to be omitted due to collinearity and we proceeded further with dummy variables only for time in case of individual industry groups.

Though we decided to use the fixed effects model for reasons discussed in the previous section, we employed the generally accepted Hausman test to supplement our decision. The null hypothesis was that both estimation methods (fixed and random effects) are similar. The results indicated that for all the industries and for the aggregate sample, fixed effect model should be used. The results of the Hausman test are placed at Table 1 in Appendix 3.

Before proceeding further, we decided to check for any multi-collinearity between independent variables. This was done by using the Variance Inflation Factors (VIF), where values greater than 10 indicate a strong probability of occurrence of multi-collinearity. We did not find any evidence of multi-collinearity in the aggregate sample and individual industry groups. Table 2 in Appendix 2 presents the VIF values. We also checked for normality of the residual by using the Shapiro-Wilk test with a null hypothesis that the residuals are uniformly distributed. Table 2 (Appendix 3 ) shows that they were generally normal with $p$-values above 0.05

The key results of the fixed effects model are reported in the following paragraphs. ${ }^{2}$

Through Table 1, we present an overview of $\mathrm{r}^{2}$ generated by the model, both for the aggregate sample and for individual industry groupings.

\footnotetext{
${ }^{2}$ Detailed Regression output is available on request
} 
Table - 1: Model $\mathbf{r}^{2}$

\begin{tabular}{|l|l|l|l|l|l|l|l|l|}
\hline & \multicolumn{2}{|l|}{ Industry } \\
\cline { 2 - 9 } & $\begin{array}{l}\text { Model } \\
\text { Statistics }\end{array}$ & Aggregate & Automobile & Banking & FMCG & Infrastructure & IT & Pharmaceuticals \\
\hline \multirow{2}{*}{$\mathrm{r}^{2}$} & Within & 0.7408 & 0.878 & 0.9001 & 0.867 & 0.8811 & 0.8684 & 0.8058 \\
\cline { 2 - 10 } & Between & 0.8333 & 0.1338 & 0.1005 & 0.5037 & 0.0501 & 0.8453 & 0.7224 \\
\cline { 2 - 9 } & Overall & 0.6885 & 0.1588 & 0.1651 & 0.4271 & 0.3036 & 0.7273 & 0.4799 \\
\hline & F Value & 108.42 & 50.93 & 63.75 & 46.13 & 52.45 & 44.69 & 29.36 \\
\cline { 2 - 9 } & Prob> F & 0.000 & 0.000 & 0.000 & 0.000 & 0.000 & 0.000 & 0.000 \\
\hline
\end{tabular}

Within $\mathrm{r}^{2}$ refers to the observation of effects over time within firms; between $\mathrm{r}^{2}$ refers to the observation of effects between firms at any one point in time. The $r^{2}$ values for the aggregate sample suggest that all independent variables account for $68 \%$ overall variation in the Enterprise Value (EV), $83 \%$ variation within companies over time and $74 \%$ variation between companies at one point in time. The model fit according to $r^{2}$ appears to be good in majority cases except Automobile and Banking industries.

Table 2 presents the coefficients from the fixed effects model.

We instantly take note of the fact that though the majority of independent variables establish a significant causal relationship with $E V$ at the collective level, there are industry level peculiarities in terms of how a particular variable does or does not affect the $E V$.

Value creation in the automobile sector stands out as one that is significantly affected by most independent variables, though it does not seem to care much for the net profit margins. A broader overview reveals that the market does not seem to read too much into the net profit margin for most industrial sectors except the FMCG and Infrastructure sectors.

In the banking sector, variables related to profitability like ROCE have a more significant relationship with $E V$ as compared to efficiency ratios. This is expected as most efficiency related variables are related to sales, whereas the banking sector would be more concerned with capital requirements, understanding and managing risk to ensure survival and profitability.

The FMCG industry is characterized by fast turnover and relatively low cost products. The fixed asset turnover ratio (FATO) is therefore a significant factor in its value creation, as are the gross and net profits. 
Table - 2: Regression Coefficients

\begin{tabular}{|c|c|c|c|c|c|c|c|}
\hline EV & Automobile & Banking & FMCG & Infra & IT & Pharma & Aggregate \\
\hline$R_{1}$ & $0.2 * *$ & $1.43 *$ & $0.644 * *$ & $0.582 * *$ & -0.116 & $0.319^{*}$ & $0.712 * *$ \\
\hline$R_{2}$ & $0.134^{*}$ & $2.013 * *$ & 0.0122 & $0.358 * *$ & 0.0599 & $0.422 * *$ & $0.883 * *$ \\
\hline$R_{4}$ & $-0.091 * *$ & 0.019 & 0.031 & 0.031 & $0.995 * *$ & 0.017 & $-0.132 * *$ \\
\hline$R_{3}$ & $0.481 * *$ & -0.015 & -0.043 & 0.059 & $-0.101 * *$ & $0.377 * *$ & $0.625^{* *}$ \\
\hline$R_{5}$ & $0.395 * *$ & 0.209 & $-0.263^{*}$ & $-0.344 * *$ & $0.537 * *$ & $-0.176^{*}$ & $0.328 * *$ \\
\hline $\boldsymbol{R}_{6}$ & -0.041 & -0.047 & $0.226^{* *}$ & $0.372 * *$ & -0.039 & -0.044 & $-0.1631^{*}$ \\
\hline dummy2005 & $-1.000^{* *}$ & $-0.871 * *$ & $-1.33 * *$ & $-2.05^{* *}$ & $-0.806^{* *}$ & $-1.044 * *$ & $-1.406^{* *}$ \\
\hline dummy 2006 & $-0.773^{* *}$ & $-0.817 * *$ & $-0.974 * *$ & $-1.437 * *$ & $-0.558 * *$ & $-0.704 * *$ & $-1.279 * *$ \\
\hline dummy 2007 & $-0.695 * *$ & $-0.628 * *$ & $-0.849 * *$ & $-0.971 * *$ & $-0.404 * *$ & $-0.548 * *$ & $-0.95 * *$ \\
\hline dummy 2008 & $-0.611 * *$ & $-0.461 * *$ & $-0.623^{* *}$ & $-0.587 * *$ & $-0.245^{*}$ & $-0.484 * *$ & $-0.614^{* *}$ \\
\hline dummy2009 & $-0.600 * *$ & $-0.393 * *$ & $-0.724 * *$ & $-0.656^{* *}$ & -0.149 & $-0.516^{* *}$ & $-0.337^{* *}$ \\
\hline dummy2010 & $-0.21 * *$ & $-0.19 * *$ & $-0.405^{* *}$ & $-0.261^{*}$ & -0.011 & $-0.213^{* *}$ & $-0.355^{* *}$ \\
\hline dummy2011 & -0.0935 & 0.024 & $-0.203^{*}$ & -0.121 & -0.015 & -0.087 & -0.153 \\
\hline dummyauto & - & - & - & - & - & - & -0.094 \\
\hline dummybanking & - & - & - & - & - & - & $3.65 * *$ \\
\hline dummyFMCG & - & - & - & - & - & - & $-0.96^{* *}$ \\
\hline dummyPharma & - & - & - & - & - & - & $-0.549 * *$ \\
\hline dummyIT & - & - & - & - & - & - & $-1.524 * *$ \\
\hline Constant & 4.06 & 4.59 & 6.02 & 4.83 & 0.703 & 3.82 & 1.266 \\
\hline
\end{tabular}

** Significant at $1 \%$ level of significance * Significant at $5 \%$ level of significance

It is interesting to note that the whereas the sales related efficiency ratios like $\frac{C F O A}{S}$ and $\frac{E V}{S}$ have the least explanatory power in most industry groups, they emerge as significant in case of IT sector while surprisingly, none of the profitability ratios emerge significant.

Table 2 also shows that while the gross profit measure $\frac{E V}{E B I T D A}$ has a positive relationship with $E V$, the net profit margin mostly comes up as negative and insignificant factor. ROCE has a strong positive impact on $E V$ for most industries while the nature of FATO and $\frac{E V}{S}$ is mixed. Overall, sales related efficiency ratios do not appear to have a significant relationship with $E V$ at individual industry level.

As surmised earlier in the paper, the passage of time has a negative and significant relationship with enterprise value $(E V)$. A look at the dummy variables for time shows that the value of a firm/industry should be a result of its current performance and business practices rather than past events. The coefficients keep getting more negative as we move back in time.

At the collective level, we note that banking sector has a significantly positive contribution to $E V$ during the time frame studied, while other sectors show a significant but negative effect (except automobile sector), infrastructure sector being the reference point.

\section{Conclusion}

We set out to examine the impact of operating efficiency on firm valuation. Enterprise value was used as a measure of firm value and apart from the dummy variables for entities and time, six ratios that gauge the operating efficiency and to some extent, profitability of a firm were used as dependent variables. In order to 
ensure exogeneity, we used the fixed effects model to carry out the analysis on the panel data for 90 companies, subdivided into six industrial sectors in India. At the aggregate level, all variables significantly affected the enterprise value. However, inter-industry attributes varied across industries. Gross profitability, return on capital employed and fixed assets turnover emerged as the factors that have a significant impact on the enterprise value in the inter-industry scenario while net profit margin and sales related ratios did not appear to have a major impact on the firm's value. Enterprise value and time were negatively related, indicating that it is the recent, instead of past performance, that impacts value. In the overall scenario, banking sector had a positive and significant contribution towards value creation.

\section{References}

Beccalli E., Casu B., Girardone C., "Efficiency and Stock Performance in European Banking," Journal of Business Finance and Accounting, 33 (1\&2) (2006): 245 -262

Chu. S.F and Lim G.H., "Share Performance and Profit Efficiency of Banks in an Oligopolistic Market: Evidence from Singapore", Journal of Multinational Financial Management, 8 (1998):155 -168

Dehuan, Jin and Zhenhu, Jin, "Firm performance and Stock returns: An Empirical study of the Top Performing Stocks listed on Shanghai Stock Exchange", Academy of Accounting and Financial Studies Journal, Volume 12, Issue 1 (2008)

Ioannidis C., Molyneux P., and Pasiouras F., "The Relationship between Bank Efficiency

and Stock Returns: Evidence from Asia and Latin America" University of Bath, School of Management, Working paper Series, 2008.10

Janardhan, Naik G., "Operating efficiency of Banks in India", The Journal of IndianManagement\& Strategy, Volume 12, Issue 1 (2007): 36-46

Joshua Kirkwood and DaehoomNahm, "Australian Bank Efficiency and its Relation to Stock Return," The Economic Record, 82 (2006): 253-267

Seetharaman, A. and John Rudolph Raj, "An Empirical Study on the Impact of Earnings per share on Stock Prices of a listed Bank in Malaysia”, International Journal of Applied Economics and Finance, 5(2) (2011): 114126

Appendix 1

Sample Composition

\begin{tabular}{|l|l|l|l|}
\hline \multicolumn{2}{|l|}{ IT Sector } & Pharmaceutical Sector & Banking Sector \\
\hline S. No & Companies & Companies & Banks \\
\hline 1 & TCS & AurbindoPharma & Axis Bank \\
\hline 2 & Infosys & Biocon & HDFC Bank \\
\hline 3 & NIIT Tech & Dr. Reddy & ICICI Bank \\
\hline 4 & KPIIT Cummins & Cipla & SBI \\
\hline 5 & CG - Vak & Glenmark & PNB \\
\hline 6 & Geo Metric & Lupin & UBI \\
\hline 7 & Sonata Software & Sun Pharma & OBC \\
\hline 8 & Tata Elxsi & UniChem Lab & Bank of Baroda \\
\hline 9 & Zen Technologies & Torrent Pharma & Canara Bank \\
\hline 10 & Dan Law Technologies & Coral Laboratories & Vijay Bank \\
\hline 11 & Spanco Ltd & Novartis & Dena Bank \\
\hline 12 & Intel Vision Software & Venus Remedies & IDBI \\
\hline 13 & Blue Star Infotech & ShasunPharma & Indian Overseas Bank \\
\hline 14 & Ace Software & Auro Laboratories & Corporation Bank \\
\hline 15 & Zenith Computers & Nectar & Kotak Mahindra Bank \\
\hline
\end{tabular}




\begin{tabular}{|l|l|l|l|}
\hline \multicolumn{2}{|l|}{ Automobile Sector } & Infrastructure Sector & FMCG Sector \\
\hline S. No & Companies & Companies & Companies \\
\hline 1 & Ashoka Leyland & Anant Raj & ITC \\
\hline 2 & BEML Ltd & Ansal Properties \& Infra & Britannia \\
\hline 3 & Hero Motor Corp & Era Infra & Colgate Palmolive \\
\hline 4 & M\&M & Ganesh Housing & Godfrey Philips \\
\hline 5 & Tata Motors & GVK Power \& Infra & Godrej Consumers \\
\hline 6 & Swaraj ISUZU & Hindustan Construction & Dabur \\
\hline 7 & Force Motors & IVRCL & Emami \\
\hline 8 & TVS & Jai Prakash Associates & United Brewries \\
\hline 9 & Maharashtra Scooters & JMC Projects & RadicoKhaitan \\
\hline 10 & Maazda & Madhucon Infra & Ruchi Soya \\
\hline 11 & Maruti & Nagarjuna Construction & Kohinoor Foods \\
\hline 12 & CEAT India & Patel Enggineering & DFM Foods \\
\hline 13 & Majestic Auto & Reliance Infrastructure & Asian Paints \\
\hline 14 & TVS Srichakra & Simplex Infrastructure & Agro Tech Foods \\
\hline 15 & VST Tillers & SPML Infra & Marico \\
\hline
\end{tabular}

\section{Appendix 2}

\section{Description of Variables}

1. Enterprise Value $(E V)=$ Equity Value + Net Debt + Preferred Stock + Minority Interest where,

Equity Value $=$ Equity value of firm is also known as Market capitalization of a firm.

Market Capitalization $=$ Total no. of outstanding share $\times$ Current share price

Net Debt $=$ Total Debt - Cash \& Cash equivalents (Marketable securities, Treasury bills)

Minority Interest $=$ Interest on Non - Controlling shareholders

(Minority interest is the percentage of the subsidiary's book value of equity that the parent firm does not own)

Preferred stock $=$ It is not convertible into common stock

\section{2. $\frac{E V}{E B I T D A}$}

This ratio represents the relationship between gross profit and enterprise value of a firm

3. Return On Capital Employed (ROCE)

Return on Capital Employed represents the efficiency of company in terms of profitability of a firm expressing its operating profit as a percentage of capital employed.

\section{ROCE $=\frac{\text { Operating Profit }}{\text { Capital Employed }}$ where, Capital Employed $=$ Total Assets - Current Liabilities}

High value of return on capital employed represents that firm is highly efficient to generate more revenue per rupee of capital employed.

4. Enterprise Value/Sales (EV/S)

It shows the total value of firm to its sales. It represents the cost of buying a firm's sales. This ratio is very useful during corporate restructuring of firm 
Or

$$
\frac{E V}{S}=\frac{\text { Equity Value }+ \text { Net Debt }+ \text { Preferred Stock }+ \text { Minority Interest }}{\text { Sales }}
$$

$\frac{E V}{S}=\frac{\text { Equity Value }+(\text { Total Debt }- \text { Cash/Cash Equivalents })+\text { Preferred Stock }+ \text { Minority Interest }}{\text { Sales }}$

5. $\frac{C F O A}{S}$

Cash flow from operating activities/sales ratio represents the efficiency of company in terms of amount of cash generated by the company from its core business as a percentage of its sales.

$$
C F O A=\frac{\text { Net Cash Flow from Operating Activities }}{\text { Sales }}
$$

6. Fixed Asset Turnover Ratio (FATO)

It represents the firm's operating efficiency in terms of converting fixed assets into sales. High fixed asset turnover ratio represents that company is highly efficient in managing its fixed assets.

$$
F A T O=\frac{\text { Net Sales }}{\text { Total Fixed Assets }}
$$

7. Net Profit Margin (NPM)

This ratio shows the efficiency of company in converting its sales into profitability.

$$
N P M=\frac{\text { Profit after Tax }}{\text { Sales }} \times 100
$$

A higher net profit margin ratio represents that a company is more efficient at converting sales into actual profit.

\section{Appendix 3}

Table 1: Hausman Test

\begin{tabular}{|l|l|l|l|l|l|l|l|}
\hline \multicolumn{7}{|l|}{ Industry } \\
\hline $\begin{array}{l}\text { Test } \\
\text { Statistics }\end{array}$ & $\begin{array}{l}\text { Aggregat } \\
\text { e }\end{array}$ & $\begin{array}{l}\text { Automobil } \\
\text { e }\end{array}$ & $\begin{array}{l}\text { Bankin } \\
\text { g }\end{array}$ & $\begin{array}{l}\text { FMC } \\
\text { G }\end{array}$ & $\begin{array}{l}\text { Infrastructur } \\
\text { e }\end{array}$ & IT & $\begin{array}{l}\text { Pharmaceutical } \\
\text { s }\end{array}$ \\
\hline $\mathrm{Chi}^{2}$ & 174.96 & 35.35 & 60.39 & 64.71 & 44.31 & $\begin{array}{l}33.6 \\
6\end{array}$ & 51.33 \\
\hline $\mathrm{P}>\mathrm{Chi}^{2}$ & 0.000 & 0.000 & 0.000 & 0.000 & 0.000 & $\begin{array}{l}0.00 \\
0\end{array}$ & 0.000 \\
\hline
\end{tabular}


Table 2: Collinearity, Residual Normality and Coefficient Significance

\begin{tabular}{|c|c|c|c|c|c|c|c|c|c|c|c|c|c|c|c|c|c|c|c|c|c|c|c|c|c|c|c|c|}
\hline \multicolumn{29}{|c|}{ INDUSTRY } \\
\hline Variables & \multicolumn{4}{|c|}{ AUTOMOBIIE } & \multicolumn{4}{|c|}{ BANKING } & \multicolumn{4}{|c|}{ FMCG } & \multicolumn{4}{|c|}{ INFRA } & \multicolumn{4}{|c|}{ IT } & \multicolumn{4}{|c|}{ PHARMA } & \multicolumn{4}{|c|}{ AGGREGATE } \\
\hline & VIF & $t^{t}$ & pyt & \begin{tabular}{|l|} 
shapiro \\
Wilk \\
Test
\end{tabular} & UF & $\mathrm{t}$ & prt & \begin{tabular}{|c|} 
Shapiro \\
Wilik \\
Test
\end{tabular} & UF & $\mathrm{t}$ & $p t$ & \begin{tabular}{|c|} 
shappiro \\
Wilk \\
Test
\end{tabular} & MF & $\mathrm{t}$ & 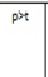 & \begin{tabular}{|c|} 
Shapirf \\
Wilk \\
Test
\end{tabular} & $\mathrm{MF}$ & $t$ & $p t$ & \begin{tabular}{|c|} 
shapiro \\
Wik \\
Test
\end{tabular} & VIF & $t$ & $p s t$ & $\begin{array}{l}\text { shapiro } \\
\text { Wik } \\
\text { Test }\end{array}$ & VIF & $t$ & pyt & \begin{tabular}{|l} 
Shapiro \\
Wilk \\
Test
\end{tabular} \\
\hline EV & & & & 0.124 & & & & 0.97 & & & & 0.087 & & & & 0.604 & & & & 0.502 & & & & 0.184 & & & & 0.319 \\
\hline EVEBITDA & 1.94 & 4.73 & 0.000 & 0.102 & 6.73 & 2.5 & 0.014 & 0.072 & 1.39 & 7.19 & 0.000 & 0.063 & 2.08 & 6.1 & 0.000 & 0.423 & 4.24 & -1.66 & 0.100 & 0.314 & 3.6 & 2.29 & 0.024 & 0.827 & 2.25 & 6.62 & 0.000 & 0.122 \\
\hline ROCE & 2.73 & 25 & 0.014 & 0.243 & 5.05 & 3.36 & 0.001 & 0.143 & 1.52 & 0.24 & 0.813 & \begin{tabular}{|l|l|}
0.0872 \\
\end{tabular} & 6.23 & 3.17 & 0.002 & 0205 & 3.75 & 0.93 & 0.353 & 0.104 & 4.01 & 5.07 & 0.000 & 0.223 & 2.08 & 11.03 & 0.000 & 0.134 \\
\hline EVS & 2.11 & 759 & 0.001 & 0.439 & 55 & .0 .08 & 0.995 & 0.253 & 1.73 & . 0.49 & 0.623 & 0.0726 & 437 & 0.53 & 0.598 & 0.671 & 1.32 & 3.08 & 0.003 & 0.215 & 3.82 & 529 & 0.000 & 0.125 & 5.64 & 6.38 & 0.000 & 0.384 \\
\hline CFOAS & 3.41 & -3.51 & 0.102 & $0.0 \$ 86$ & 1.14 & 1.14 & 0.255 & 0.239 & 1.62 & 0.22 & 0.360 & 0.164 & 1.61 & 2.03 & 0.035 & 0.163 & 7.87 & 11.33 & 0.000 & 0.065 & 1.15 & 0.72 & 0.476 & 0.206 & 1.38 & -2.83 & 0.000 & 0.263 \\
\hline FATO & 3.41 & 5.64 & 0.000 & 0.183 & 2.45 & 2.27 & 0.016 & 0.157 & 1.49 & 2.43 & 0.017 & 0.0741 & 1.89 & .3 .1 & 0.302 & 0.261 & 2.14 & 6.32 & 0.000 & 0.491 & 1.35 & 235 & 0.021 & 0.103 & 3.2 & 434 & 0.000 & 0.168 \\
\hline NPM & 2.5 & -1.12 & 0.264 & 0.153 & 1.52 & -0.49 & 0.627 & 0.134 & 1.56 & 3.36 & 0.001 & \begin{tabular}{|l|l|}
0.192 \\
\end{tabular} & 5.52 & 6.04 & 0.000 & \begin{tabular}{|l|}
0.282 \\
\end{tabular} & 2.94 & -0.86 & 0.392 & \begin{tabular}{|l|l|}
0.179 \\
\end{tabular} & 3.52 & -0.8 & 0.425 & 0.064 & 2.02 & 2.36 & 0.019 & 0.218 \\
\hline dummyate & - & $\cdot$ & $\cdot$ & - & - & $\cdot$ & - & \begin{tabular}{|l|}
$\cdot$ \\
\end{tabular} & - & - & - & \begin{tabular}{|l|}
$\cdot$ \\
\end{tabular} & - & - & $\cdot$ & \begin{tabular}{|l|}
$\cdot$ \\
\end{tabular} & - & - & $\cdot$ & \begin{tabular}{l|l}
$\cdot$ \\
\end{tabular} & - & - & - & - & 1.89 & -0.61 & 0.545 & 0.000 \\
\hline dummybanking &. & $\cdot$ & . & - &. & $\cdot$ & - &. & $\cdot$ &. & - &. & . & - &. & $\cdot$ &. & - &. & $\cdot$ & - &. &. &. & 4.01 & 15.64 & 0.000 & 0.000 \\
\hline dunanyFMCG & $=$ & $=$ & $=$ & $=$ & $=$ & $=$ & $=$ & $=$ & $=$ & $=$ & $=$ & $=$ & 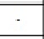 & $=$ & $=$ & $=$ & $=$ & $=$ & $=$ & $=$ & $=$ & $=$ & $=$ & $=$ & 2.06 & -5.82 & 0.000 & 0.000 \\
\hline dunnyPharma & - & - & - & - & - & - & - & - & - & - & - & - & - & - & - & - & - & - & - & - & - & - & - & - & 1.79 & -3.59 & 0.000 & 0.000 \\
\hline dunnylT & $\cdot$ & . & . & - & $=$ & $\cdot$ & - &. & $\cdot$ &. & - & . &. & - & $=$ & $\cdot$ & $\cdot$ & $=$ & $\cdot$ & . & - & . & . & $\cdot$ & 1.75 & -10.11 & 0.000 & 0.000 \\
\hline dumy2005 & 1.81 & -15.12 & 0.000 & 0.000 & 3.06 & -9.51 & 0.000 & 0.000 & 1.87 & -14.48 & 0.000 & 0.000 & 2.15 & -16.84 & 0.000 & 0.000 & 1.96 & 825 & 0.000 & 0.000 & 1.93 & -12.72 & 0.000 & 0.000 & 1.77 & -8.27 & 0.000 & 0.000 \\
\hline dummy2006 & 195 & -10.88 & 0.000 & 0.000 & 2.73 & -9.35 & 0.000 & 0.000 & 1.88 & $-11: 13$ & 0.000 & 0.000 & 2.32 & -9.35 & 0.000 & 0.000 & 2.08 & .5 .36 & 0.000 & 0.000 & 1.84 & -8.69 & 0.000 & 0.000 & 1.84 & -736 & 0.000 & 0.000 \\
\hline dumny2007 & 1.88 & .10 .33 & 0.000 & 0.000 & 2.33 & .7 .81 & 0.000 & 0.000 & 1.87 & .953 & 0.000 & 0.000 & 2.02 & -6.98 & 0.000 & 0.000 & 1.94 & 4.15 & 0.000 & 0.000 & 1.78 & .694 & 0.000 & 0,000 & 1.79 & -5.56 & 0.000 & 0.000 \\
\hline durny 2008 & 1.78 & -9.39 & 0.000 & 0.000 & 1.7 & .728 & 0.000 & 0.000 & 1.83 & -7.03 & 0.000 & 0.000 & 2.18 & -3.95 & 0.000 & 0.000 & 1.90 & -2.61 & 0.011 & 0.000 & 1.79 & -6.14 & 0.000 & 0.000 & 1.77 & -3.62 & 0.000 & 0.000 \\
\hline dumny 2009 & 1.79 & 9.09 & 0.000 & 0.000 & 1.78 & 3.69 & 0.000 & 0.000 & 1.84 & 87.76 & 0.000 & 0.000 & 2.14 & 3.41 & 0.000 & 0.000 & 1.87 & -1.57 & 0.120 & 0.000 & 1.83 & -6.42 & 0.000 & 0.000 & 1.79 & -1.96 & 0.000 & 0.000 \\
\hline dumny2010 & 1.82 & -3.12 & 0.002 & 0.000 & 1.86 & -3.02 & 0.003 & 0.000 & 1.76 & -4.82 & 0.000 & \begin{tabular}{|l|l|}
0.000 \\
\end{tabular} & 199 & -2.16 & \begin{tabular}{l|l}
0.033 \\
\end{tabular} & 0.000 & 191 & -0.12 & 0.902 & 0.000 & 1.76 & \begin{tabular}{|l|}
-2.73 \\
\end{tabular} & 0.008 & 0.000 & 1.77 & -2.08 & 0.038 & 0.000 \\
\hline duany2011 & 1.79 & -1.42 & 0.158 & 0.000 & 2.06 & 0.31 & 0.759 & 0.000 & 1.77 & \begin{tabular}{l|l}
.2 .43 \\
\end{tabular} & 0.017 & 0.000 & 1.88 & -1.09 & 0.279 & 0.000 & 1.81 & -0.16 & 0.872 & 0.000 & 1.76 & \begin{tabular}{l|l}
1.13 \\
\end{tabular} & 0.26 & 0.000 & 1.76 & -0.90 & 0.368 & 0.000 \\
\hline
\end{tabular}


The IISTE is a pioneer in the Open-Access hosting service and academic event management. The aim of the firm is Accelerating Global Knowledge Sharing.

More information about the firm can be found on the homepage:

http://www.iiste.org

\section{CALL FOR JOURNAL PAPERS}

There are more than 30 peer-reviewed academic journals hosted under the hosting platform.

Prospective authors of journals can find the submission instruction on the following page: http://www.iiste.org/journals/ All the journals articles are available online to the readers all over the world without financial, legal, or technical barriers other than those inseparable from gaining access to the internet itself. Paper version of the journals is also available upon request of readers and authors.

\section{MORE RESOURCES}

Book publication information: http://www.iiste.org/book/

\section{IISTE Knowledge Sharing Partners}

EBSCO, Index Copernicus, Ulrich's Periodicals Directory, JournalTOCS, PKP Open Archives Harvester, Bielefeld Academic Search Engine, Elektronische Zeitschriftenbibliothek EZB, Open J-Gate, OCLC WorldCat, Universe Digtial Library, NewJour, Google Scholar

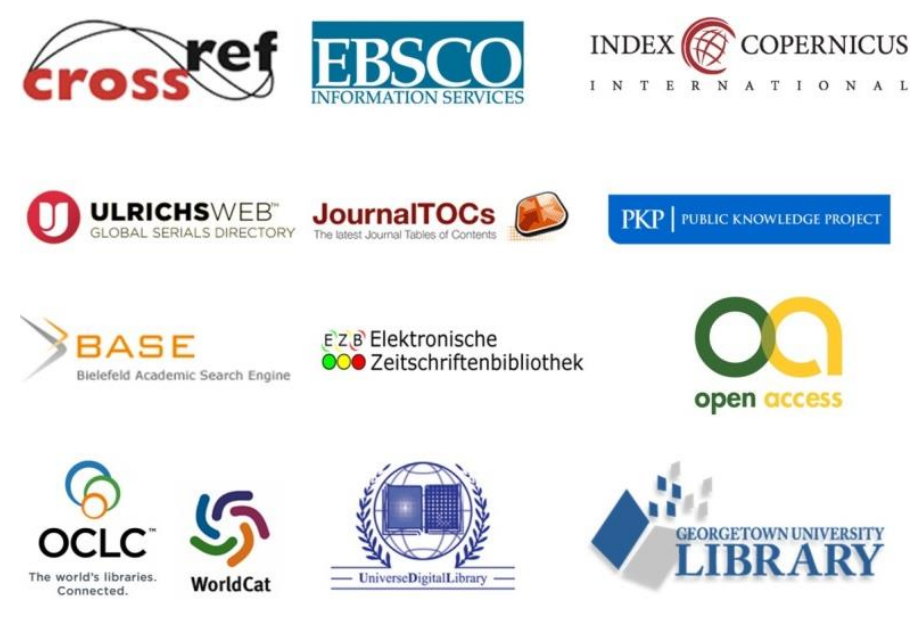

